\title{
Assessment of Mixing Height at Qena/Upper Egypt Based on Radiosonde Data
}

\author{
S. M. El Shazly, Kh. O. Kasse m*, A. A. Hass an, Hala. E. A. \\ Atmospheric physics group, Physics Dep., Faculty of science, S. V.U., Qena, Egypt
}

\begin{abstract}
Radiosonde and surface meteorological data have been carried out in south valley university meteorological station at Qena / upper Egypt for estimation of maximu m and minimu m mixing height MH during the periods (2006 - 2008) and (October 2004 - September 2005), respectively. The effect of some meteorological para meters such as temperature $\left(\mathrm{T}^{0} \mathrm{C}\right)$, wind speed (WS m/s), and relative humidity ( $\mathrm{RH} \%$ ) on maximum MH has been studied. It is found that average daily maximu $\mathrm{m}$ MH ranges fro $\mathrm{m}(700 \mathrm{~m})$ to $(2367 \mathrm{~m})$ in winter, and fro $\mathrm{m}(567 \mathrm{~m})$ to $(2700 \mathrm{~m})$ in autumn and from $(1133 \mathrm{~m})$ to $(4860 \mathrm{~m})$ in spring, and from $(1200 \mathrm{~m})$ to $(3750 \mathrm{~m})$ in summer. Seasonal average value of maximum MH reaches its maximu $\mathrm{m}(2425 \mathrm{~m}$ and $2481 \mathrm{~m}$ ) during spring and summer, respectively, while, it attains its minimu $\mathrm{m}$ ( $1418 \mathrm{~m}$ and $1504 \mathrm{~m}$ ) during winter and autu mn, respectively. Minimu $\mathrm{m} \mathrm{MH} \mathrm{has} \mathrm{generally} \mathrm{a} \mathrm{value} \mathrm{between} 100$ and $200 \mathrm{~m}$. Seasonal average of minimu $\mathrm{m} \mathrm{MH}$ is characterized by small fluctuation. Where, it varies fro $\mathrm{m}(166 \mathrm{~m}$ and $197 \mathrm{~m})$ during spring and summer, respectively to (161 m and $173 \mathrm{~m}$ ) during winter and autumn, respectively. Monthly averages of maximu $\mathrm{m} \mathrm{MH}$ is associated forwardly with $\mathrm{T}$ and WS and associated backwardly with $\mathrm{RH}$. A model relates monthly average values of maximu $\mathrm{mH}$ at afternoon with T, WS and RH has been constructed and can be used locally for estimation of monthly average MH.
\end{abstract}

Keywords Mixing Height, Daily Variation, Seasonal Variation, Weather Parameters

\section{Introduction}

Air pollution models (Lagrangian, Eulerian or Gausian) are useful tools for evaluating emission rates and quantifying adverse pollutant effects in certain region. Stability and $\mathrm{MH}$ are two important dispersion parameters for those models. Hence, the need is raised for estimation of these two parameters. $\mathrm{MH}$ is a fundamental parameter characterising the structure of the lower troposphere. It can be defined as the height of the layer adjacent to the ground over which pollutants or any constituents emitted within th is layer or entrained into it become vertically dispersed by convection or mechanical turbulence[1]. A ir that is not moving smoothly is termed turbulent. Turbulence is described as eddies in a local air parcel that produce mixing via two mechanisms. The first of these is purely mechanical turbulence, which is caused by irregular air movement over terrain such as trees or around obstructions such as buildings. Thermal turbulence, the second mechan ism occurs as the result of radiation from the sun heating various objects. Differential surface heating occurs, which leads to s mall parcels of air moving upward. The maximum mixing height

* Corresponding author:

khphysics@yahoo.com (Kh. O. Kassem)

Published online at http://journal.sapub.org/re

Copyright (C) 2012 Scientific \& Academic Publishing. All Rights Reserved is the height of the convective layer associated with the maximu m surface temperature. The maximu m mixing height exhibits both local and seasonal variations. In addition it is affected significantly by topography and large scale air movements. Minimum values of mixing height will be observed in the late hours of the night or in the early morning hours and may be the result of a surface based inversion[2]. The pollutants which released into the air fro m any source of pollution are being continually mixed. On hot days, they are taken up extremely high a way fro $m$ the ground. In contrast to that, in cool days, the mixing height is very low and pollutants remain close to the ground.

There is an enormous uncertainty in estimation of mixing height since it is not a directly measurable variable [3, 4]. Holzworth method is the most commonly used one for calculating $\mathrm{MH}$ from temperature profile which can be obtained from radiosonde data[5]. Radiosonde is a balloon borne measurements of the vertical profiles of meteorological parameters, i.e., pressure, temperature and relative humidity, it is the most common source of data for operational determination of the MH [6].

Qena is a small city in upper Egypt. It is a place of many factories such as Aluminium factory, two factories of sugar and a factory of cement. There is strong need for estimation of $\mathrm{MH}$ in this city to be used in pollution modelling in the future. So that, the main purpose of this study is to estimate afternoon $(12 \mathrm{Z})$ and early morning $(0 \mathrm{Z}) \mathrm{MH}$ in Qena during the periods from 2006 to 2008 and from October 2004 to 
September 2005, respectively. The effect of some meteorological parameters such as temperature, wind speed, and relative humid ity on maximu $\mathrm{mH}$ has been studied and an emp irical model relates monthly values of maximum $\mathrm{MH}$ with T, WS and RH has been constructed.

\section{Location description}

Qena City $\left(26^{\circ} 17^{\prime} \mathrm{N}, 32^{\circ} 43^{\prime} \mathrm{E}, 97 \mathrm{~m}\right.$ asl) is located in Upper Egypt, about $600 \mathrm{Km}$ south of Cairo and $60 \mathrm{Km}$ north of Luxor (Figure 1). It located main ly within the narrow Nile valley which separates Egypt to two unequal dessert parts, the western and the eastern deserts. Climate of Qena is very hot, dry in summer and cold in winter. It rarely rains. Also, it receives large quantity of solar radiation, especially in summer [7].

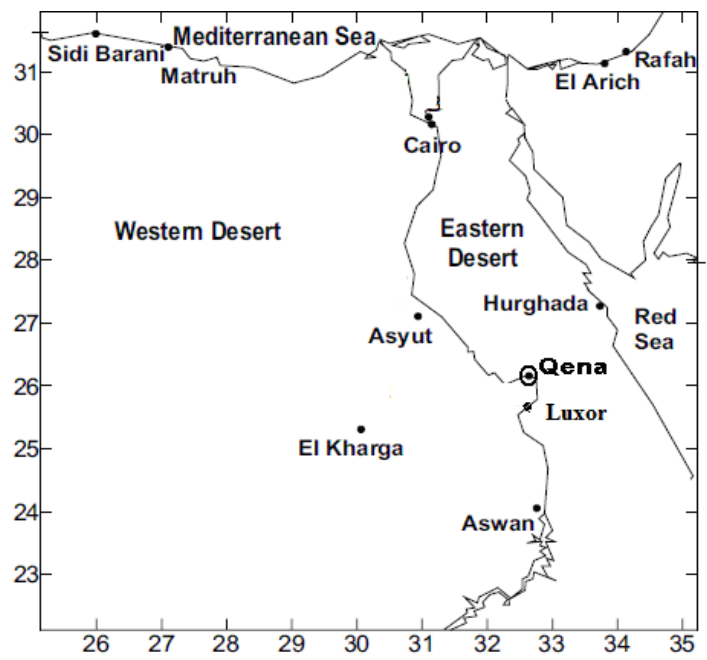

Figure 1. map of Egypt, location of studied area

\section{Materials and Methods}

Data has been collected from South valley university station at Qena, in the eastern desert part, about $6 \mathrm{Km}$ north east of Qena city. The data included surface hourly and daily values of $\mathrm{T}^{\circ} \mathrm{C}, \mathrm{RH} \%$ and $\mathrm{WS} \mathrm{m} / \mathrm{sec}$, during the period (2004-2008). Within this period, upper air data (Pressure, WS, WD, T and RH as functions of altitude) have been conducted using radios onde at afternoon ( $12 \mathrm{Z}, 2 \mathrm{pm})$ during the period from 2006 to 2008, and at morning (00 Z, 2 am) during the period from October 2004 to September 2005. Radiosonde data at (12 Z) represented 1041 records during the total period (1095dayes), while that at (00 Z) represented 346 records during the total period (365 days).

The complete radiosonde system consisted of 1- A balloon-borne radiosonde instrument package, 2- A radio receiver, 3-A tracking unit, and 4- A recorder .

The balloon-borne radiosonde instrument package is the main component of the radiosonde, Model M2k2-DC. complete specifications can be found in http://www.meteom odem.com/rproduit.php?nom=M2K2-DC. The following weather sensing instruments are located within or attached to this package. resistance thermistor for measuring temperature, hygristor sens or for measuring humidity and an aneroid barometer for measuring pressure. The radiosonde package is carried aloft by a spherically shaped balloon. The balloon is made of a film of natural or synthetic rubber (neoprene). A radio receiver model SR2K2 Modem is used for receiving the telemetry signal transmitted from the radiosonde. Complete specifications can be found in http://www.meteo modem.com/gproduit.php?nom=SR2 $\mathrm{K} 2$. Highly directional radio direction finding antenna is used also to obtain the wind speed and direction at various levels in the atmosphere by tracking the radiosonde and determining the azimuth and elevation angles. The data are recorded automatically during the flight and then processed.

For determining $\mathrm{MH}$, three preliminary categories are distinguished by vertical temperature profiles: an elevated inversion layer, a ground based inversion layer, and no inversion layer. The following describe the three cases:

For an elevated inversion layer, the mixing height is taken as the base of the lowest inversion $[8,9]$.

If a ground-based inversion has been detected in the radiosonde temperature profile, the mixing height has been identified with the ground based top height [10].

If an inversion is not present, the mixing height is taken as the altitude of level defined by the first intersection of the temperature profile with dry-adiabatic line this method is called Holzworth method or dry adiabatic method $[11,12,13$, $14,15,16]$.

\section{Results and Discussion}

\subsection{Maxi mum Mixing Height}

Daily variation of average maximum $\mathrm{MH}$ at afternoon in Qena during the period (2006 - 2008) is shown in figure 2. Fro $m$ this figure one can see that average values of maximum $\mathrm{MH}$ during winter and autumn are relatively lower than that during spring and summer. It ranges from $(700 \mathrm{~m})$ to $(2367$ $\mathrm{m})$ in winter, and from $(567 \mathrm{~m})$ to $(2700 \mathrm{~m})$ in autumn and from $(1133 \mathrm{~m})$ to $(4860 \mathrm{~m})$ in spring, and from $(1200 \mathrm{~m})$ to (3750 $\mathrm{m}$ ) in summer.

Seasonal average, maximum, minimum and standard deviation values of maximum $\mathrm{MH}$ during the same period have been investigated. It is clear that seasonal average values of maximum $\mathrm{MH}$ ranged from low values (1418 m) and $(1504 \mathrm{~m})$ to relatively high values $(2425 \mathrm{~m})$ and $(2481 \mathrm{~m})$ during winter, autumn, spring and summer, respectively. By the same seasonal consequences, seas onal maximu m values of maximum MH ranged from (2367) and (2700) to (4860) and (3750). While, seasonal minimum values of maximum $\mathrm{MH}$ ranged from (700) and (567) to (1133) and (1200). A lso, standard deviation ranged from relatively low values (353) and (458) to relatively high values (668) and (604) as shown in figure (3). This may be attributed to the re latively high day to day variability of temperature and wind speed in spring and summer seasons. 


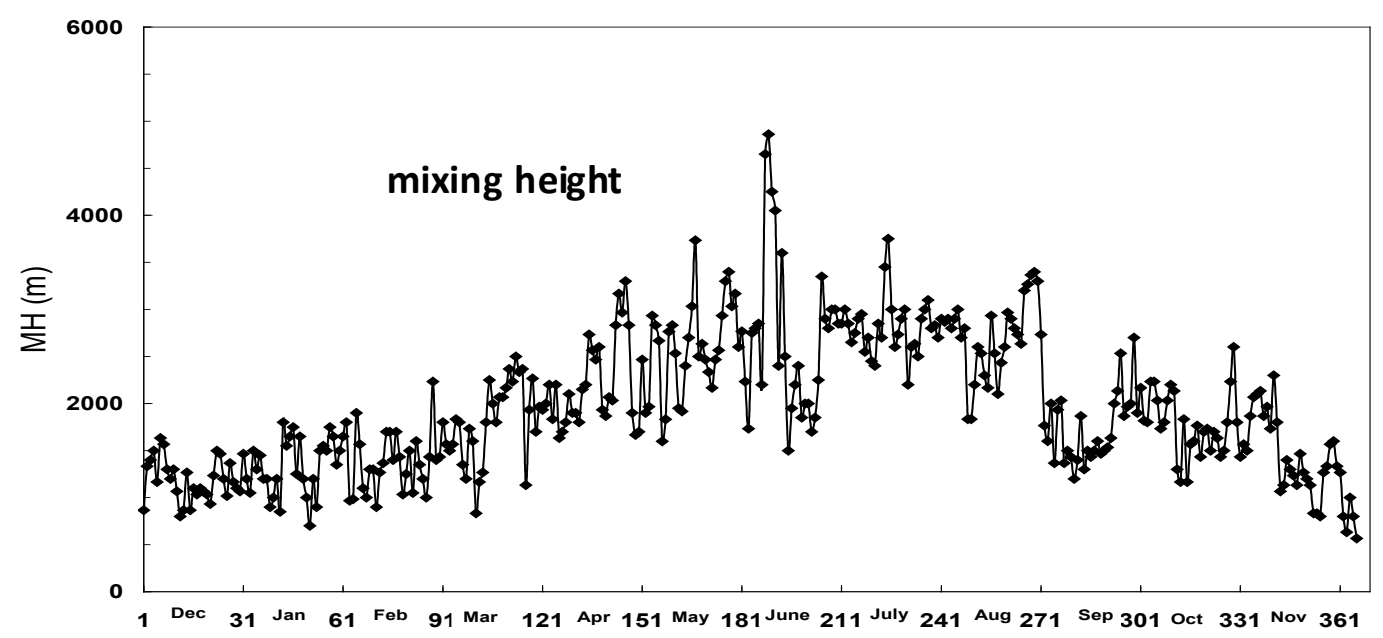

Figure 2. Daily variation of average maximum $M H$ at afternoon time in Qena, during the period(2006 - 2008)

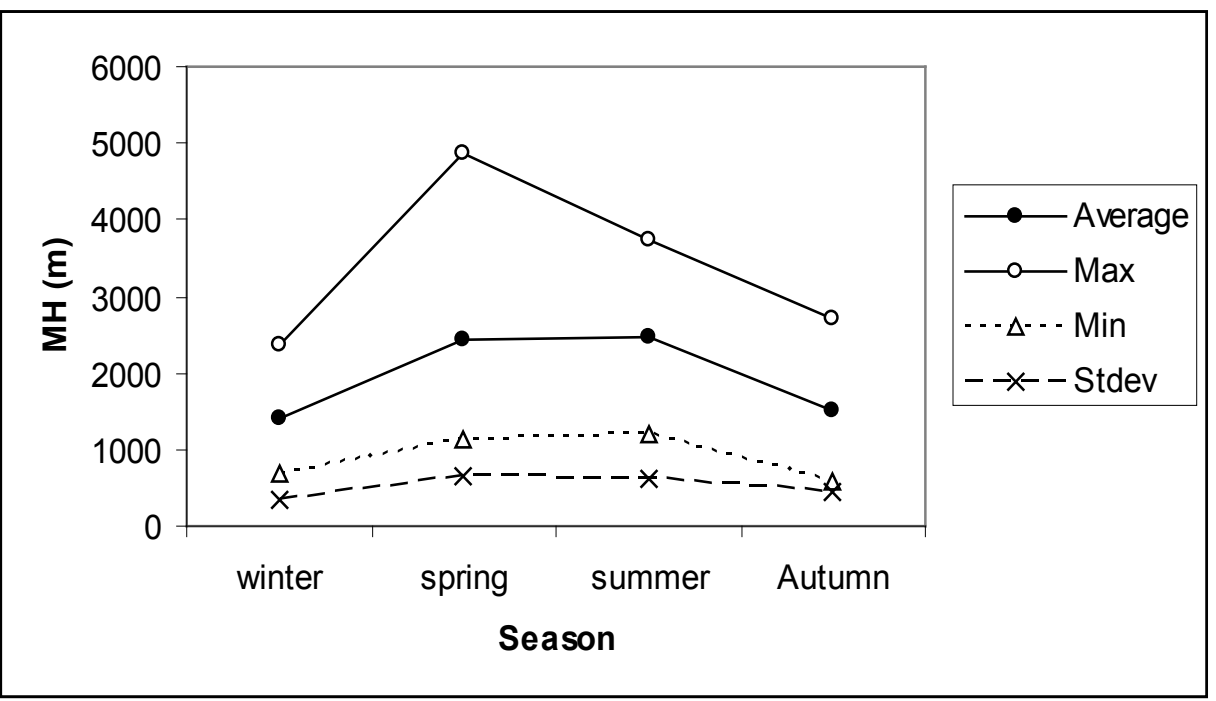

Figure 3. Seasonal average, maximum, minimum, and standard deviation variation of maximum MH at aft ernoon time in Qena (2006- 2008)

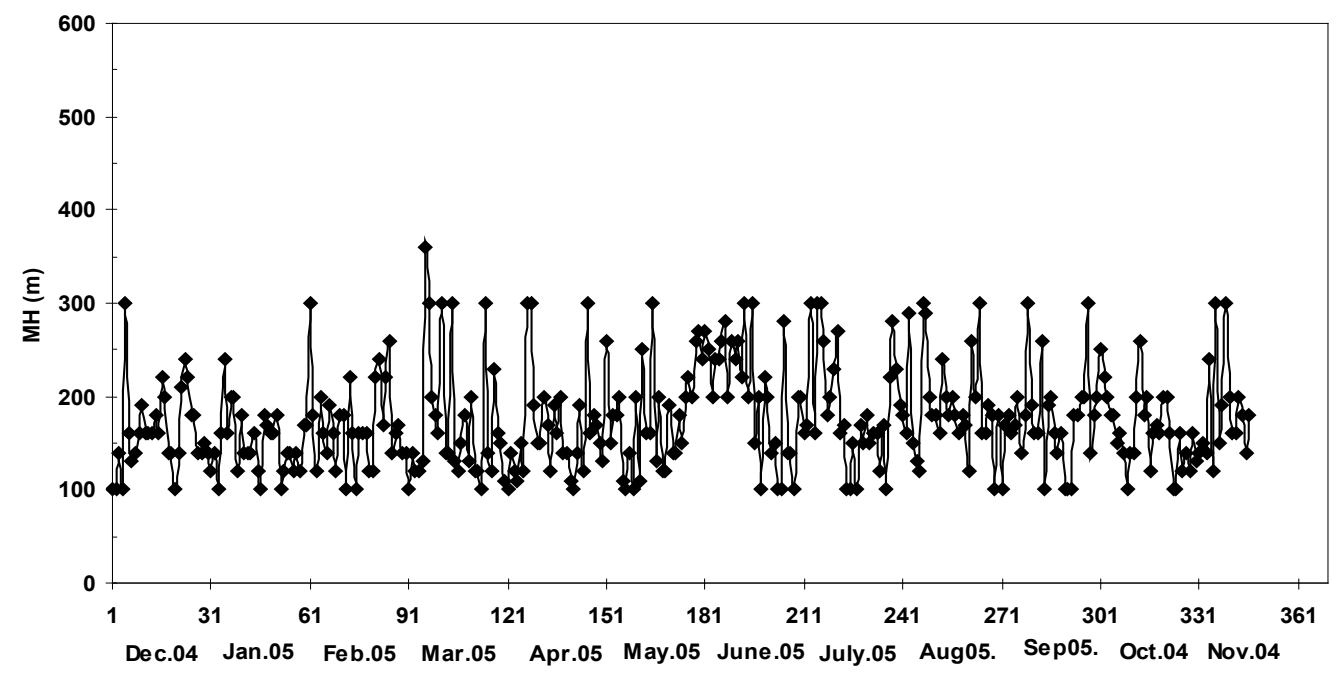

Figure 4. Daily variation of minimum MH in Qena, during the period (October 2004 - September 2005) 


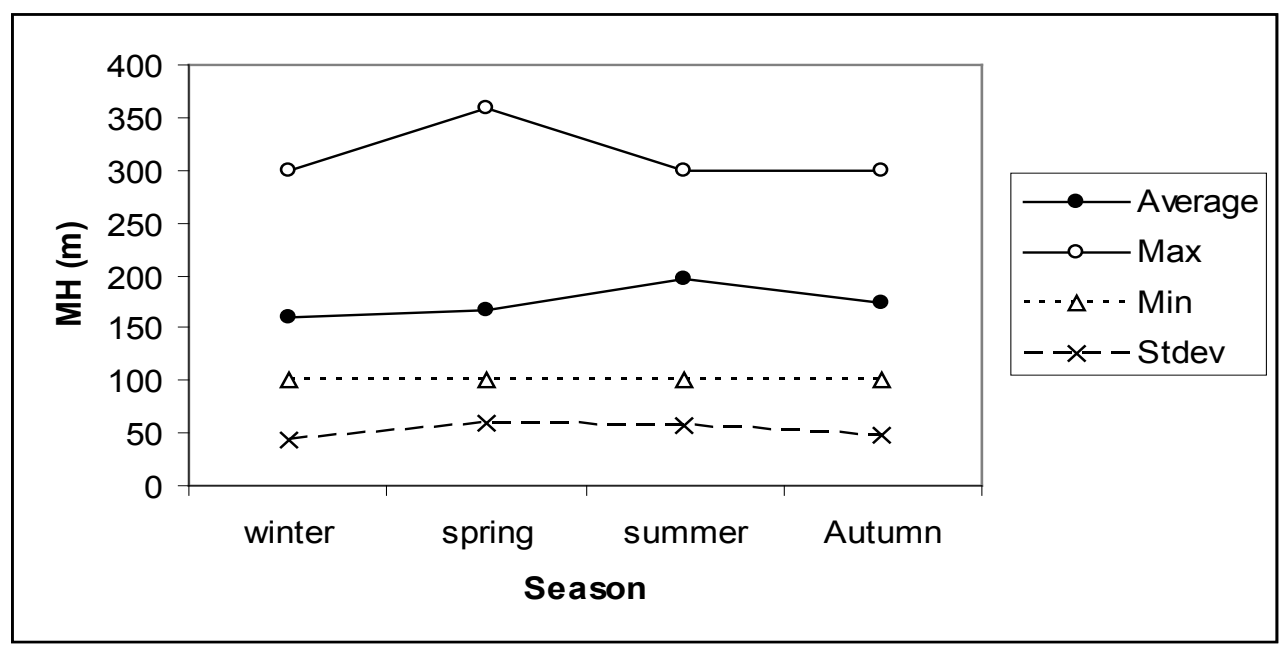

Figure 5. Seasonal average, maximum, minimum, and standard deviation variation of minimum $\mathrm{MH}$ at early morning in Qena, during the period (October 2004 - September 2005)

\subsection{Minimum Mixing Height}

Daily variation of minimum $\mathrm{MH}$ during the period (October 2004 - September 2005) is illustrated in figure 4. About (80\%) of the total number of the recorded data (346) are characterized with values of minimum $\mathrm{MH}$ range from $(100 \mathrm{~m})$ to $(200 \mathrm{~m})$. The nu mber of nights that characterized by min imu $\mathrm{m} \mathrm{MH}$ between (200 and $300 \mathrm{~m}$ ) represented only (19\%), most of them (95\%) observed during spring and summer seasons.

Seasonal variation of average, maximum, minimum and standard deviation of min imu $\mathrm{mH}$ during the same period is studied. It is found that seasonal average values of minimu $\mathrm{mH}$ ranged from low values $(161 \mathrm{~m})$ and $(166 \mathrm{~m})$ during winter and spring, respectively, to (173 m) and (197 $\mathrm{m}$ ) during autumn and summer, respectively. Seasonal maximum values of minimum $\mathrm{MH}$ range from $(300 \mathrm{~m})$ during winter, autu $\mathrm{mn}$ and summer to $(360 \mathrm{~m})$ during spring. Seasonal minimum values are the same $(100 \mathrm{~m})$ during all seasons. Standard deviation ranges from relatively low values $(42 \mathrm{~m})$ and $(48 \mathrm{~m})$ during winter and autumn, respectively to relatively high values $(59 \mathrm{~m})$ and $(58 \mathrm{~m})$ during spring and summer seasons, respectively, as shown in figure 5 . Th is may be attributed to the relatively high day to day variability of temperature and wind speed in spring and summer seasons.

At night time, the radiation inversion is the most common form of surface inversion and occurs when the earth's surface cools rapidly. As the earth cools, so does the layer of air close to the surface. If this air cools to a temperature below that of the air above, it beco mes very stable, and the layer of warmer air impedes any vertical motion. Radiation inversions usually occur in the late evening through the early morn ing under clear skies with calm wind.

\subsection{Effect of Some Meteor ological Parameters on Afternoon MH}

Figure 6 and Table 1 illustrate monthly average variation of maximum $\mathrm{MH}$ and corresponding values of $\mathrm{T}, \mathrm{RH}$ and
WS estimated at afternoon time in Qena during the period ( 2006- 2008). It is clear that minimum monthly average values of maximum $\mathrm{MH}$ occurred in cold months especially in December (1193 m), while maximum values occurred in hot months especially in July $(2809 \mathrm{~m})$. There is positive association between monthly averages of maximu $\mathrm{m} \mathrm{MH}$ and both of $\mathrm{T}$ and WS, in the same time, there is negative association with $\mathrm{RH}$. Where, $\mathrm{T}$ monthly average value reaches its minimum value in cold months, January (19.8o C) and December $(22.4 \mathrm{oC})$, and reaches its maximum in hot months, June (40.1 o C) and August (39.8o C). RH monthly average value reaches its min imum value in June (9.1\%) and May $(9.5 \%)$, and its maximum in January (29.9\%) and December $(27,9 \%)$. WS monthly average value reaches its minimu $\mathrm{m}$ value in December $(2 \mathrm{~m} / \mathrm{s})$, and January $(2.9 \mathrm{~m} / \mathrm{s})$, and its maximum in July $(5 \mathrm{~m} / \mathrm{s})$, and June $(5.7 \mathrm{~m} / \mathrm{s})$. The highest $\mathrm{MH}$ occurrence in summer, and spring months may be attributed to increasing the frequency of unstable and slightly unstable atmospheric stability conditions in summer and spring in Qena[17], also, high atmospheric temperature associated with strong solar radiation and significant atmospheric turbulence lead to high $\mathrm{MH}$. Higher wind speeds lead to strong mechanical turbulence and therefore high $\mathrm{MH}$. In winter and autumn, low temperature and high frequencies of inversion result in stable atmospheric conditions and less turbulence and hence lead to low $\mathrm{MH}$. High RH also limits $\mathrm{MH}$ development and leads also to low $\mathrm{MH}[15,16]$.

Table 2 shows the equation and correlation coefficient between monthly average values of maximum $\mathrm{MH}$ and each of T, WS, and RH. It is clear that there are strong correlation between them.

These strong correlation Coeffic ients lead us to suggest an empirical model for calculating monthly average values of maximum $\mathrm{MH}$ using data of monthly average values of $\mathrm{T}$, WS and $\mathrm{RH} \%$ measured at $(2 \mathrm{pm})$. Multiple regression analysis has been used and a model in the form:

$$
\mathrm{MH}=\mathrm{A} \mathrm{T}+\mathrm{BWS}+\mathrm{CRH}+\mathrm{D}
$$




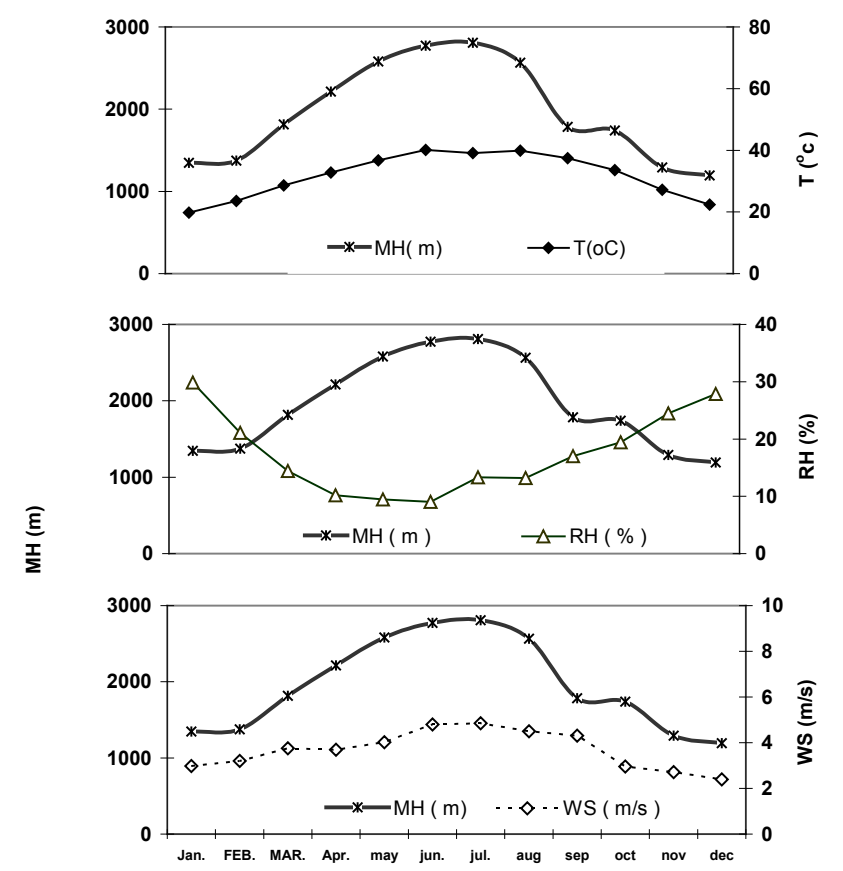

Figure 6. Monthly variations of average maximum $\mathrm{MH}$ and corresponding values of $\mathrm{T}, \mathrm{RH}$, and WS at afternoon time in Qena duringthe period (2006-2008)

Table 1. Monthly average values of maximum $\mathrm{MH}$ and corresponding values of T, RH, and WS at afternoon time in Qena during the period ( 20062008)

\begin{tabular}{ccccc}
\hline Month & $\mathrm{MH}(\mathrm{m})$ & $\mathrm{T}\left({ }^{\circ} \mathrm{C}\right)$ & $\mathrm{RH}(\%)$ & $\mathrm{WS}(\mathrm{m} / \mathrm{s})$ \\
\hline January & $\mathbf{1 3 4 7}$ & $\mathbf{1 9 . 8}$ & $\mathbf{2 9 . 9}$ & $\mathbf{2 . 9 8}$ \\
February & 1375 & 23.6 & 21.1 & 3.20 \\
march & 1816 & 28.6 & 14.4 & 3.75 \\
April & 2214 & 32.8 & 10.2 & 3.69 \\
May & 2581 & 36.8 & 9.50 & 4.02 \\
June & $\mathbf{2 7 7 4}$ & $\mathbf{4 0 . 1}$ & $\mathbf{9 . 1 0}$ & $\mathbf{4 . 7 9}$ \\
July & $\mathbf{2 8 0 9}$ & $\mathbf{3 9 . 1}$ & $\mathbf{1 3 . 3}$ & $\mathbf{5 . 0 0}$ \\
August & 2565 & 39.8 & 13.2 & 4.50 \\
September & 1785 & 37.5 & 17.0 & 4.31 \\
October & 1740 & 33.5 & 19.4 & 2.96 \\
November & 1292 & 27.2 & 24.5 & 2.71 \\
December & $\mathbf{1 1 9 3}$ & $\mathbf{2 2 . 4}$ & $\mathbf{2 7 . 9}$ & $\mathbf{2 . 0 0}$ \\
\hline
\end{tabular}

Table 2. The equation and correlation coefficient between monthly average values of maximum MH and each of T, WS, and RH

\begin{tabular}{|c|c|c|}
\hline Meteorological parameter & equation & correlation \\
\hline Temperature $\left({ }^{\circ} \mathrm{C}\right)$ & $\mathrm{MH}=73.709 \mathrm{~T}-384.53$ & 0.88 \\
\hline wind speed (m/s) & $\begin{array}{c}\mathrm{MH}=653.4 \mathrm{WS}- \\
447.51\end{array}$ & 0.89 \\
\hline Relative humidity (\%) & $\begin{array}{c}\mathrm{MH}=-75.011 \mathrm{RH}+ \\
3266.2\end{array}$ & -0.88 \\
\hline
\end{tabular}

Has been constructed. Where $\mathrm{A}, \mathrm{B}$, and $\mathrm{C}$ are the coefficients of the, T, WS and RH variables, respectively. D is a constant involves any other not used effective para meters. The obtained regression model takes the form:

$$
\mathrm{MH}=18.6 \mathrm{~T}+305 \mathrm{WS}-30.3 \mathrm{RH}+775
$$

With multiple correlation coefficient $(\mathrm{r}=0.94)$.

For studying the efficiency of this model, It has been used for calculating monthly average values of maximum $\mathrm{MH}$ during the period from (October 2004 to April 2005). Figure
7 illustrates variation of monthly average values of measured and calculated maximum MH. It is clear that the model performs qualitatively good.

Figure 8 represents the relation between measured and calculated values of maximum $\mathrm{MH}$. The correlation coefficient between the two variables is $(0.74)$ which indicates that this model is quantitatively rather good. The relation between the calcu lated and measured values of $\mathrm{MH}$ takes the form

$$
\text { MHcal }=1.1035 \mathrm{MHm}+249.16
$$

Where, MHcal is the calculated mixing height and $\mathrm{MHm}$ is the measured mixing height. It is clear that there is over estimation for the calculated $\mathrm{MH}$ values represented in average by $249.16 \mathrm{~m}$. The coefficient of MHm is 1.1035 represents the ratio between the calculated and measured $\mathrm{MH}$. this value is not so far from unit and reflects reasonable agreement between measured and calculated values.

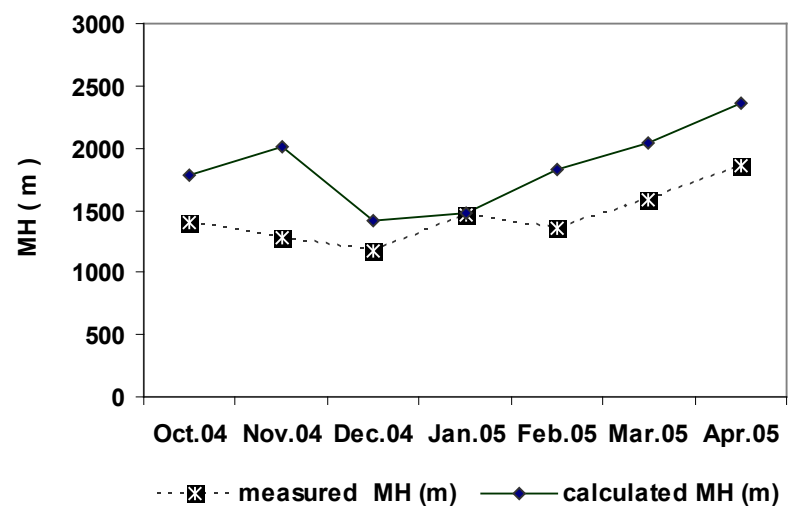

Figure 7. Measured and calculated monthly average maximum $\mathrm{MH}$ variation in Qena / Upper Egypt during the period from October 2004 to April 2005

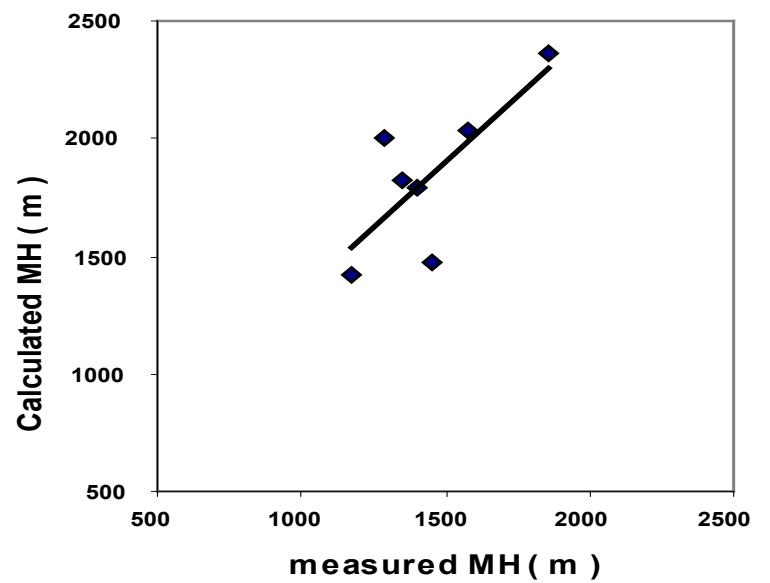

Figure 8. Relationship between measured and calculated monthly average maximum MH in Qena / Upper Egypt during the period from October 2004 to April 2005

\section{Conclusions}

Radiosonde and surface meteorological data have been carried out in south valley university meteorological station 
at Qena / upper Egypt for estimation of maximum and minimum $(\mathrm{MH})$ during the periods (2006 - 2008) and (October 2004 - September 2005), respectively. It is found that average daily maximu $\mathrm{m}(\mathrm{MH})$ ranges from $(700 \mathrm{~m})$ to $(2367 \mathrm{~m})$ in winter, and from $(567 \mathrm{~m})$ to $(2700 \mathrm{~m})$ in autumn and from $(1133 \mathrm{~m})$ to $(4860 \mathrm{~m})$ in spring, and from $(1200 \mathrm{~m})$ to $(3750 \mathrm{~m})$ in summer. While, seasonal average values of maximum $\mathrm{MH}$ varies from relatively low values $(1418 \mathrm{~m})$ and $(1504 \mathrm{~m})$ during winter and autumn, respectively, to relatively high values $(2425 \mathrm{~m})$ and $(2481 \mathrm{~m})$ during spring and summer respectively. Seasonal average values of minimu $\mathrm{mH}$ are characterized by small fluctuation, $(161 \mathrm{~m})$ and $(173 \mathrm{~m})$ during winter and autumn respectively, and (166 $\mathrm{m})$ and (197 m) during spring and summer respectively.

Monthly average values of maximu $\mathrm{mH}$ varies forward with both of T and WS and backward with RH. A model estimating monthly average values of maximu $\mathrm{m} M H$ using $\mathrm{T}$, WS and RH data has been constructed and can be used locally for estimation of Monthly averages of maximum $\mathrm{MH}$.

The relatively high values of maximum $(\mathrm{MH})$ during day time and low values during night time should be taken into account for arranging the working hours of the different factories emit pollutants to the atmosphere of Qena.

\section{REFERENCES}

[1] Seibert, P., Beyrick, F., Gryning, S. E., Joffre, S., Ramussen, A. and Tercier, P. "Review and intercomparison of the operational methods for the determination of the mixing height." Atmos. Environ., 34, 1001 - 1027, 2000.

[2] Roger D. Griffen. "Principales of air quality management." seconde edition. Taylor \&Francis group LLC. P 111.-113. 2007.

[3] Nath, S., Patil, R.S. "A simple model to determine in situ mixing height growth from surface measurement." Environmental Fluid Mechanics 3 (3), 195-219. 2003.

[4] Nath. S., Patil. R. S. "Prediction of air pollution concentration using an in situ real time mixing height model." Atmospheric Environment 40, 3816-3822. 2006.

[5] Ulke, A. G., Mazzeo, N. A. "Climatological aspects of the daytime mixing height in Buenos Aires City." Argentina. Atmospheric Environment Vol 32, No. 9, PP. 1615 - 1622, 1998.
[6] Kim, S.-W., Yoon, S.-C., Won, J-G., Choi, S-C. "Ground-based remote sensing measurements of aerosol and ozone in an urban area: A case study of mixing height evolution and its effect on ground-level ozone concentrations." Atmospheric Environment 41, 7069-7081, 2007.

[7] El-Shazly, S. M., Mohamed Abuel-Kassem, M. and Abdel-Azeem M. A.. " A statistical study on weather impaction concerning human well-being in the region of Qena, Egypt." Bull. Fac. Sci., Assuit Univ., 24(1-A), P-P. 189-206. 1995.

[8] Robert B. "Determination of mixing heights from data collected during the 1985 SCCCAMP field program." Journal of Applied Meteorology, 30, 598-606. 1991.

[9] Coulter R. L. "A comparison of three methods for measuring mixid layer height." Journal of applied meteorology. 18, 1495 $-1499,1979$.

[10] Hassanein, A. .A., Abdel-Wahab, M. M., Metwally, Z. "Preliminary study of the lower tropospheric inversion statistics in Cairo." Meteorological research Bulletin. Vol. 8, No. 2, October 1976.

[11] Holzworth, G. C. " Estimates of mean maximum mixing depths in the contiguous United States." Monthly Weather Review, Vol. 92, No. 5, pp. 235-242. 1964.

[12] Holzworth, C. G. "Mixing depths, wind speeds and air pollution potential for selected locations in the United States." Journal of Applied Meteorology, 6, 1039 - 1044. 1967.

[13] Holzworth, C. G. "Mixing depths, wind speeds and potential for urban pollution throughout the contiguous United States." EPA. Office of Air Programs Publication No. AP - 101, 118 pp. 1972:

[14] Vittal Murty, K. P. R.; Viswanadham, D. V. and sadhuram, Y., "Mixing heights and ventilation coefficients for urban centres in India." Boundary layer meteorology, 19, 441 - 451. 1980.

[15] Cheng, S. Y., Huang, G. H., Chakma A., Hao, R. X., Liu, L., Zhang, X. H. "Estimation of atmospheric mixing heights using data from airport meteorological stations." J. ENVIRON. SCI. HEALTH, A 36 (4), 521 - 532. 2001.

[16] Cheng, S. Y, Jin, Y. Q., Liu, L., Huang, G. H., Hao, R. X., Jansson, C. R. E. " Estimation of atmospheric mixing height over large areas using data from airport meteorological stations." J. ENVIRON. SCI. HEALTH, A 37 (6), 991 - 1007 , 2002.

[17] Adam, M. El-Nouby, Sayed, M. Elshazly. "Diurnal variation of atmospheric stability at Qena (Upper Egypt). MAUSAM, 59, 1, 69-76. January 2008 . 